\title{
ACTOR RELATION IN THE DYNAMIC OF INTER-REGIONAL COOPERATION POLICY (Case Study: Development Program of Metropolitan Area of Banjar Bakula, South Kalimantan Province)
}

\author{
TAUFIK ARBAIN
}

\author{
(opinibanua@gmail.com) \\ Faculty of Social and Political Sciences, Lambung Mangkurat University
}

\begin{abstract}
Several studies have shown that the success in the inter-regional cooperation was influenced by coordination, commitment, participation, variance of cooperation, structure and format of as a factor that contributes the determinant in the successful cooperation between regions. This research was a qualitative research, conducted on the object of policy of inter-regional cooperation Banjarbakula Program, South Kalimantan Province, February 2017-February 2018. The result of this study states that the success of cooperation to political will. In fact these factors did not stand alone since the aspect of actor relationship as the determinant aspect drove those factors effectively. This article aims to examine the aspect of actor relationship cooperation between regions was influenced by the dynamics of actor relationships in constructing factors as suggested by the previous experts. The actors involved in the interregional cooperation became the triggers of coordination, commitment and participation to the success and failure, as well as the effectiveness of regional cooperation policy. Structural obstacles, ego-centric, minimally budget and no visionary planning could be overcome as long as the dynamics of actor relationships were managed properly.
\end{abstract}

Keywords: actor relation, inter-regional cooperation

\section{OVERVIEW}

This study emerged from the important issues which related to the government collaboration as a policy choice to fill in the absence of public services and to make development budget efficient. In the context of government, the inter-regional cooperation is commonly used to resolve the problems in the public services among governments, between the government and private party, as well as the cross-country government. However, the cooperation is a 'shortcut' in solving porblems in order to achieve effectivity, efficiency and a better quality of public services, as well as to strengthen the social bound among the government in the interest of nation security (Keban, 2010).

The focus of government collaboration in the good governance perspective is to involve various public actors, such as society and private sectors, in the making of public policy. In order to realize the productive, effective, and efficient government, there is a definite need of the involvement of policy actors. In this context, the collaboration is meant as an answer to the limitation of local government capacity in performing the government since it is still struggling in the Weberian type bureaucracy paradigm. Therefore, the existence of policy actors in the government collaboration during the process of formulation and implementation of policy is as an arena of relation and constructive interaction in filling the shortcomings and strengths between actors. 
Donahue and Zechauser (2011: 30) has defined that "collaborative governance can be thougt of a form of agency relationship between government as principal and private players as agent". The definition from Donahue and Zechauser informed the importance of relation built among actors, both as the regulators and the private sectors as well as the public as the implementer. This fact emphasizes that collaboration is a part of the inevitability of dependence among actors and could be explained as the process involving the common norm and interaction-relation of mutualism.

However, the discourse of inter-regional collaboration is still stagnant on common determinants of effectiveness, such as a form of institutions, coordination, commitment, variation of sector collaborated, formal position between the collaborating parties, transparancy, political support, capacity, power distribution, mechanism, creationinnovation, complete database, participation, support of the government above it, etc. (Charlote, E-Jenning (2006), O'Toole (2004), Wiechart(2002), Santyeka (1999), Young Oran (1992)).

In connection to that fact, there are several points behind the importance of the issue in answering the academic anxiety. The developed dicourses related to that issue are as follows. First, the inter-regional collaboration should not ignore the presence of networking among actors as the issue to encourage the success of cooperation policy among governments in the context of implementing the inter-governmental networks. To date the cooperation among government is dominantly relying on the aspects of commitment, coordination, form of institution, cooperation model and leader's commitment. It is the form of releasing the conventional approach trap of Weberian type bureaucracy. Second, the government system of a nation determines the flexibility and effectivity of inter-regional collaboration in the decision making as well as the choice of collaboration policy management. The implementation of inter-regional collaboration which had a long centralistic bureaucracy history holds the confusion and trap of authority structures (Klijn, in Kickert, et.al., 1999). The presence of regulation as the supportive factor as well as an obstacle in the success of collaboration policy is still found. Third, the collaboration among government is necessary to solve the development problem of the century which process involves many policy actors as the manifestation of the good governance.

The case of inter-regional cooperation in South Kalimantan Province with Banjarbakula Program which launched in 1998 in order to sustain the regions development has faced a significant slackness. In almost 18 years, the slow progress of the process was marked with the policy products which were not-yet optimal, in form of policy output and outcome. Some of those policy products are the uneffective utilization and use of sharedinfrastructure among government, and the weak coordination and common perception of inter-regional cooperation. The cases of collaboration planning, such as the regional choice of Type A Terminal and Final Processing Place (TPA)became the scene of conflict and an interest seizing among actors in the regency/city, especially between the City Government of Banjarmasin, the City Government of Banjarbaru and the Regency Government of Banjar. Those cases have proven there was a counter-productive of an interest relation and among actors which implicated to the sectoral/regional ego effect.

Based on that assumption, the development progress of the implementation of interregional collaboration in Banjarbakula Program, South Kalimantan Province has left the issue of success, either high, medium or low. Therefore, this study attempts to uncover the other side which related to the success of the governor's era towards the dynamics of interregional cooperation policy which lies in the use of the actor relations perspective. In that 
situation, this study would focus on the efforts to find the explanation on the presence of actor relation which supported the preferences of actor's value in the success of interregional collaboration, in the relational model, the policy style to the explanation of the dynamic aspect of formulation and implementation of the inter-regional collaboration policy.

\section{THEORETICAL FRAMEWORK: INTER-REGIONAL COLLABORATION AND ACTOR RELATION}

Inter-governmental cooperation is defined as "an arrangement between two or more governments for accomplishing common goals, providing a service or solving a mutual problem" (Patterson, 2008). The definition implied the presence of shared-interest supported two or more local governments in providing the shared-service or solving the problems together. In other words, it is a joint arrangement. The nature of collaboration is often intepreted as a voluntary action, but it is not an act of arbitrary since the collaboration has a certain goals and target to be achieved by parties involved in the collaboration. Discussion on intergovernmental management and intergovernmental relation started to emerge on many literatures and studies from public management experts in the middle of the 20th century (McGuire, 2006; O,Toole, 2004). Michael McGuire stated that "intergovernmental management is more than just intergovernmental relationships".

In networking pattern, there is no central authority structure. All goals are the result of the deal made by all joined members in the inter-regional collaboration forum as the realization of a common action (Klijn, in Kickert, et.all., 1999). The difference between these organizations' characteristics is often ambiguous in the realization of inter-regional collaboration in Indonesia, the country with quite a long history of centralistic bureaucracy. Opinion on the work of several factors in the regionalization and regional collaboration could be traced back from the regionalization process and inter-regional communication model. Ansell and Gash (2008: 543-571) defined the collaborative governance as "a governing arrangement where one or more public agencies directly engage non-state stakeholders in a collective decision-making process that is formal, concensus-oriented, and deliberative and that aims to make or implement public policy or manage public programs or assets". It was similar to Culpepper's opinion (Sranko, 2011) that defined the collaborative governance as "collaborative governance is the availability of institutions that promote interaction among governmental and non-governmental actors, without state actors monopolizing problem definition, goal-setting, or methods of implementation".

From the time series, some pioneers in the discussion of regionalization and interregional cooperation could be known, among others, are Goggin (1990), Weicchart (2002), O 'Toole (2004), Thomson (2006), Rendell as well as Yablonsky (2006), and Bryson, Crosby and Stone in Keban (2009). If Goggin have not yet identified the pushing factors and obstacles in the inter-regional collaboration which worked in several governmental level, Weicchart (2002) has firmed that global pressure, limited capacity and potential pressure, local ego pressure were the obstacles and pushing factors.

Figures in the inter-regional collaboration, such as Philips, Lawrence and Hardy (2000), suggested that the definition of collaboration captured more on the aspects of activities and relationships. Then Bardach (1998) who based on Moore's (1996) view provided a definition of collaboration as two or more joint activities intended to create a public value. An interactive process involved groups of rational autonomous actors who used shared-rules, organizational norms or structures to act in the collective decision making (Wood \& Gray, 1991).

Furthermore Innes and Booher (2010) emphasized the view that stated the collaboration process described a collaborative network with diversity, interdependence and 
authentic dialogue imbendded. Interdependence would lead to a will to compromise until finally it reached a consensus (Supianti, 2014: 80). As stated by Robert in Ratri, SA, (2007), in general, the pattern of relationships occured between actors or stakeholders could be seen as (a) a cooperative relationship characterized by partnership relationships and mutual support for activities, and (b) conflict-related relationships characterized by conflicting opinions and interests in activities.

This fact becomes the background of this research, that is to choose a government collaboration study to be investigated in the perspective of networking among actors (actor relations) in order to answer the challenges of scientific development and the paradigm of New Public Governance as new way of thinking in the 21st century (Osborne, 2010). In this case, New Public Governance focuses on five principles: (a) social political governance, (b) public policy governance, (c) administrative governance, (d) contract governance, (e) network governance (Osborne, 2010). So it means that a study on collaborative governance is opened to the possibility to include aspects of actor relations (networking among actors) along with their allies.

In this case, the presence of actor relation concept is considered able to solve the problems faced by the government on the bureaucratic obstacles and the issue of absence of regulation. Although it is very possible it also raises its own problems due to the agenda carried by different actors, various interests, consistency of the agreed agenda, including the commitment and role of the actor to the dynamics of the actor seeing from issues to be cooperated.

According to Sabartier (1986, in Parson, 2005), the existence of actor's value preferences in the analysis, ideas and information held by actors was the most important thing in driving the change (policy dynamics). Therefore the actors were believed to take steps spreading the ideas, opinions and information regarding their interests to other actors, including forming new opinions and hoping they could be accepted by the public. It means that the policy dynamics delivered the cooperative relationships and inter-actor conflicts so the presence of policy 'moderators' or brokers, both in the formulation stage and intergovernmental cooperation policy stages was possible.

Furthermore, with stakeholder's value preferences, Schemeer (1999) identified the role of actors, consensus, actor background, communication, motives and agendas, ideas in policy interventions and resources owned. In the context of inter-regional collaboration policy research of Banjarbakula Program in South Kalimantan Province, actor relations at least relied on reality to identify the background of actors, motives and agendas, to the interests, resources and communication and tendency of patteren used by actors. That is to see the theoretical contribution in explaining the relationship among actors which encourages the dynamics of inter-regional cooperation policies from the era to era of Governor of South Kalimantan, supported by actor orientation theory (Norman Long, 1999) and policy character theory (Harmon, 1969).

This research sets forth the presence of actor relations as a concept to answer the inadequacy of answers on the successful inter-regional cooperation (novelty), especially the relation of formulation dynamics and implementation of inter-regional cooperation policies with the thesis arguments as the novelty of this dissertation: "the success of inter-regional cooperation is influenced by actor relations which are built from actor's value preferences. This actor's value preferences would determine the relationship model between actors and their dynamics, both at the stage of formulation and implementation of inter-regional cooperation. 


\section{Graphic 1 Research Conceptual Framework}

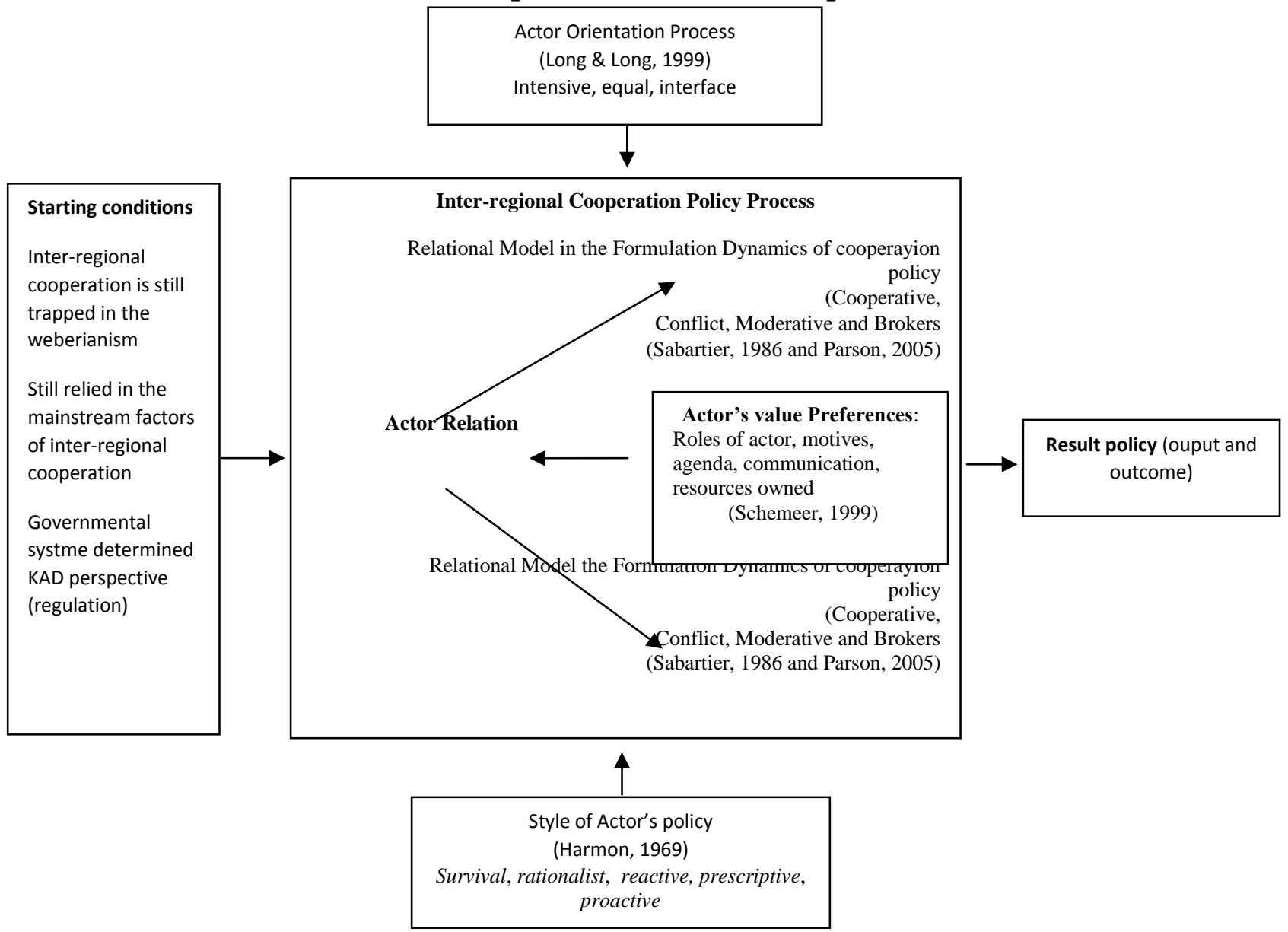

Source: Processed by Researcher, 2018 (Adapted from Ripley, Randall B, 1985, Policy Analysis in Political Science and Collaborative government model, Anshal \& Gash, 2007)

\section{RESEARCH METHOD}

There are challenges in a research involving historical aspects of a policy, constructing the novelty of research from various previous researches, including criticizing concepts related to the success of inter-regional cooperation policies. That kind of research requires an appropriate research method. Moreover, the offer of actor relations is built from the actor's value preferences in each era of government in the stages of formulation and implementation of inter-regional cooperation policies with support of the study of actor orientation theory and policy style theory. As stated by the policy expert, Majchrzak (1984), analytical techniques in the policy research consisted of focused synthesis, secondary analysis, field experiments, qualitative methods, surveys, case studies, and costbenefit/cost-effectiveness analysis. Therefore it could be said that policy research could have a tendency to use more than one method (multi-frameworks).

Therefore the strategy used in this mixed method is sequential explanatory, where the researcher tries to combine or to expand discoveries obtained from one method with the discovery of another method (QUAL $\rightarrow$ QUAN). At least it starts with the stages of a qualitative method (interview/observation/FGD) by getting an adequate explanation regarding the implementation of inter-regional cooperation policy to be followed by a 
quantitative survey method with 32 respondents as samples of key actors, primary actors and secondary actors who later interpreted such a way (see Cresswell \& Clark, 2007). Activities in data analysis using interactive models, namely data reduction, data display, and conclusion drawing following the concepts given by Miles and Huberman, and Spradley (1992).

\section{FINDINGS AND DISCUSSION}

\section{Actor Relation in the Era of Governor H. Gusti Hasan Aman}

Policy of Inter-Regional Cooperation in the era of Governor H. Gusti Hasan Aman was initiated in order to answer the increasingly complex development problems, especially City of Banjarmasin which experienced congestion, increased population, poor sanitation and concentrated of infrastructure development. This reasoning underlies the need for development intersected with other regions as a whole of inter-regional cooperation in 1999.

This idea was originally initiated by Vice Governor H. Bachtiar Murad through ideas in the print media and long discussions with the secondary actors (external governments; academics, journalists and NGOs), in addition to internal government actors. The formulation stage has resulted the output which was strengthened by the MoU between regional government of Banjarmasin, Banjar and Barito Kuala in programs as follows. (1)

Preparation of Provincial Spatial Plans Regional Regulation, (2) development of regionalization of raw water supply and clean water, (3) construction of garbage final processing sites, (4) provision of mass transportation, (5) provision of public burial land, and (6) handling of floods.

In this context, primary actors (district/city government) are very easy to be partners in cooperation with key actors, as well as secondary actors. Ability of the development range designed by the provincial government is not constrained by regulatory issues and structural obstacles (centralistic). The closeness of cooperative relations encourages the dynamics of policy formulation process, which is based on the actor's value preferences (motives, agendas, resources, communication and interests). For the key actors, actor's value preferences is an integrated development achievement targets and the primary actors are expectated as those who get the direct development impacts from the Central Government and Provincial Government funds. Meanwhile for secondary actors, the actor's value preferences is a part of access representation opening and the importance of actualizing the role of government external actors in the policy cycle.

At the implementation stage, the inter-regional cooperation policy produces output in the form of preliminary studies and development coordination which is not constrained by structural obstacles. The motives and interests of the actors as well as the cooperational relations are built with rather intensive interactions, and interfaces as part of the factors that respond to the difficulties faced by the collaborating parties. Media at that time as a secondary actor played an intensive role in the interaction of information with the key actors and primary actors to provide a compressive power on the progress of inter-regional cooperation performances.

Based on this case, relation at the formulation and implementation stages is predominantly initiated by Vice Governor of South Kalimantan as Team Leader of Regional Cooperation Coordination Board (BKKSD-Badan Koordinasi Kerja Sama Daerah) mandated by the Governor, as well as the person who has a bigger actor's value preference towards the inter-regional cooperation policy called Banjarmaskuala. His ability to play and empower district/city's primary actors and secondary actors shows a close pattern of 
cooperative relations in enriching policy considerations, road maps and agenda planning, bargaining positions to other actors to the implementation.

\section{Actor Relation in the Era of Governor H.M. Sjachriel Darham}

Inter-regional cooperation in the era of H.M. Sjachriel Darham was stagnant. In the level of government policy formulation, it was confronted with the enactment of Regional Autonomy Law in 1999, which encouraged mayors and regents to tend to join the euphoria of regional and sectoral egos on the perspective of regional development. This structural obstacle caused the difficulty in providing the understanding, including coordination of development at Provincial Regional Development Planning Meeting (Musrenbangda Musyawarah Rencana Pembangunan Daerah Provinsi), and development of the interregional program of Banjarmasin Metropolitan Area. H.M. Sjachriel Darham's leadership style which tended to be confrontational and unpopulist policies created a strong intensive conflict relationship to all actors, including the internal key actors of South Kalimantan Provincial Government. Preference of each actor's value has put the key actor H.M. Sjachriel Darham as the common enemy. In the level of policy formulation, it was mapped that the tendency of key actors to have almost no motives and agendas to integrate the constructed areas since the basis of communication started with the conflict relationship.

The pattern of conflict relations which has been built since the formulation stage resulted in the implementation process stage which did not produce a significant outputs of inter-regional cooperation policies in the government. In this context, the position of key actors tended to play the character of survival policy assuming that in the process of policy formulation, there were a low responsibility and policy support. This was due to government actors restricting the politicians, public and businessmen and even journalists to participate in the policy formulation process.

That explains the relationship has an influence on formulation and implementation of the continuity of inter-regional cooperation policies when the relation between the actors experiences a deficit and affects on the policy cycle's dynamics. In this era there was a change of officials which weakened the spirit of continuing the idea of inter-regional cooperation policy in Banjarmasin Metropolitan Area.

During Governor H. M. Sjachriel Darham's administration, an instruction from the Ministry of Public Works in form of Banjarmasin Greater Workshop in Sanur, Bali, September 2000 was issued. That was the only activation related to KAD policy in Banjarmasin Metropolitan Area. Here is where the key of hierarchical relationship between key factors, namely the central government and cooperative provincial governments, took place. By many parties, that was the only momentum in this era when the government presence in order to prepare a study of regional spatial planning strategies.

\section{Actor Relation in the Era of Governor H. Rudy Arifin}

Description of actor relation in the formulation stage provides an understanding that the dynamics of inter-regional cooperation in the era of Governor H. Rudy Arifin could be said merely not to receive the inheritance of documents and MoUs, the remaining unfinished regulation homeworks, and the commitment of regional heads due to the euphoric conditions of decentralization. The absence of a legal protection relating to provincial spatial planning as an obstacle to the formulation and implementation faced by Governor H. Rudy Arifin at the beginning of his administration in 2005-2010 period in order to be an entry point to ensure which fields suitable to the public planning and needs. BKSSD Team took a quick step by building intensive structural relations with the central government and 
Regional People's Representative Assembly (DPRD) of South Kalimantan Province, including building an informal communication among actors at the policy formulation stage.

Field findings shows that there are three main problems faced by inter-regional cooperation policy in Metropolitan Banjarbakula Area Development Program. (a) The difficulty to hold a meeting of regional heads (regents/mayors) for a decision making in the framework of inter-urban cooperation. (b) There is no inter-regional meeting point regarding the points of cooperation between urban areas, such as the location of infrastructure development, financial sharing, institutional forms which operationalize the cooperation, profit to be shared and model of cooperation. (c) The legal protection for KAD area has not yet been issued since there was no regional regulation related to Banjarbakula Metropolitan RTR so that the Provincial Strategic Area Regional Regulation has not been issued and there was no Governor Regulation concerning the Development Strategic Cooperation Agency .

In the implementation, the establishment of Banjarmasin as the 9th Metropolitan seemingly became the trigger for actors involved in the interests of Banjarbakula policy to be excited again, especially due to the promise that it would be the National Strategic Areas Cooperational relation among key actors has encouraged the Ministry of Public Works to conduct a preliminary study in the form of a Regional Spatial Study which has been a stumbling block in the implementating of Banjarbakula during the two previous eras of Governor of South Kalimantan. This cooperative relationship has pushed the government of this era to reach out and influence planning agendas in the district/city governments involved in Banjarbakula. Furthermore, the expectation of regional spatial planning implementation through integrated regional development has created a synergy of development between sectors and regions as an effort to encourage the realization of spatial structures and regional spatial patterns that are safe, comfortable, productive and sustainable, and becoming part of actors' value preferences.

The accuracy of placing officials who have management and technical capabilities as well as broad networks would make it easy to establish cooperative relationships with an intensive processes. This has implications on the commitment to encourage Banjarbakula not just to wait for order from the central government, but continue to convince the central government.

This research found that the informal relationship between key actors which mutually synergized became an important note on how close the relationship between First Assistant of Government and Bappeda South Kalimantan, PUPR Office and Regional Secretariat. This informal relationship was built due to the strength of the actor's value preferences. Such informal relations, in the case of the Banjarbakula policy, have significant implications to the implementation process so there was no structural obstacles. Officials and Banjarbakula Team of this era had their integrated and connected networks, either First Assistant of Government, Head of PUPR Office, Transportation Office, Regional Secretary or Banjarbakula BKKSD Team to external parties of the provincial government. Therefore the strengthening of Banjarbakula policy seemly gained support from various parties. The link between actors' relations provideed support in breaking the structural barriers in interregional cooperation, including barriers of regulation's lacks. The form of informal relationships were alumni networks, school friends, discussion partners and informal organizations and APDN/TPDN alumni network in the technical and policy lobbies. 
Table 1 Relation Network and Banjarbakula Policy Implications

\begin{tabular}{|c|c|c|c|}
\hline No. & Relation Network & Actors & Policy Implications \\
\hline 11 & $\begin{array}{l}\text { Alumni network of } \\
\text { APDN/STPDN }\end{array}$ & $\begin{array}{l}\text { Adjutant of Head s of } \\
\text { Regency/Mayors }\end{array}$ & $\begin{array}{l}\text { By pass to ocmmunicate } \\
\text { the coordination } \\
\text { messages }\end{array}$ \\
\hline 22 & $\begin{array}{l}\text { Alumni Network of } \\
\text { Transportation } \\
\text { College }\end{array}$ & $\begin{array}{l}\text { The alumni connected to } \\
\text { the alumni in Ministry of } \\
\text { Transportation of } \\
\text { Indonesian Republic }\end{array}$ & $\begin{array}{l}\text { Encouraging project } \\
\text { lobbying and } \\
\text { accelerating the } \\
\text { approval of the proposal }\end{array}$ \\
\hline 33 & $\begin{array}{l}\text { Ministry Program of } \\
\text { Coordination } \\
\text { Experience Activation } \\
\text { Network }\end{array}$ & $\begin{array}{l}\text { Ir. Muhammad Arsyadi, } \\
\text { MT }\end{array}$ & $\begin{array}{l}\text { Encouraging project } \\
\text { lobbying and } \\
\text { accelerating the } \\
\text { approval of the proposal }\end{array}$ \\
\hline 44 & $\begin{array}{l}\text { Persuasive-frienship } \\
\text { network }\end{array}$ & $\begin{array}{l}\text { Dr. H. Suhardjo with Ir. } \\
\text { Basuki Hadimuljono } \\
\text { (Minister of PUPR in } \\
\text { Jokowi's Cabinet) }\end{array}$ & $\begin{array}{l}\text { Encouraging and } \\
\text { inviting the } \\
\text { commitment strengthen }\end{array}$ \\
\hline 55 & $\begin{array}{l}\text { Ministry Program of } \\
\text { Coordination } \\
\text { Experience Activation } \\
\text { Network }\end{array}$ & $\begin{array}{l}\text { Civil servants in PUPR } \\
\text { Office of South } \\
\text { Kalimantan with } \\
\text { Ministry of PUPR (Ir. H. } \\
\text { Martinus) }\end{array}$ & $\begin{array}{l}\text { Encouraging project } \\
\text { lobbying and } \\
\text { accelerating the } \\
\text { approval of the proposal }\end{array}$ \\
\hline
\end{tabular}

Source: Processed Data by Researcher, December 2017

\section{Actor Relation in the Era of Governor H. Sahbirin Noor}

It was interesting to observe the beginning of Paman Birin's administration in January 2016. In that era the school friendship between Dr. H. Suhadjo, M.Si. with Ir. Basuki Hadimuljono as the Minister of PUPR RI continued to be utilized for the progress of Banjarbakula's policy. As stated before, Banjarbakula's policy debut seemingly gained an additional energy due to this informal relationship has encouraged the Ministry of PUPR to pour out Rp 1 trillion fund to Banjarbakula SPAM project in Sei Rangas in 2016 and land acquisition fund of Banjarbakula's TPA.

This fact explains that actor relation determines the effectiveness of success of interregional cooperation policies as it was stated before. Actor relationships which are built up from the informal relations networks encourage the value of actor's preference. The team in Banjarbakula policy in this era has continued the pattern of utilizing informal relations (friendship) in discussing the policy programs which they handled together.

The presence of actor's value preferences possessed by key actors, especially the opportunity for interest in friendship with the Minister of PUPR RI, Banjarbakula BKSD Team in era of Governor H. Sahbirin Noor which was chaired by Dr. H. Suhardjo, prepared a series of Banjarbakula interests in the form of draft of Banjarbakula regional regulation in the proposal of Regional Legislation Program (Prolegda-Program Legislasi Daerah). These motives and agendas were constructed in the policy formulation stage of Banjarbakula handled by Government Bureau and Legal Bureau of South Kalimantan Provincial Government. It was just that since the positional change of First Assistant Government from Dr. Suhardjo, M.Si. to another official in May 2017, there was no further information regarding Banjarbakula's activation series, including the draft of Banjarbakula regional 
regulation which was expected to support the National Strategic Area $(\mathrm{KSN})$ as directed by the Ministry of PUPR.

This study found that the reality of this mutation fluctuation did not result in consolidation by those who had the authority to discuss the sustainability of Banjarbakula further. The bland relationship between key factors in Uncle Birin's government was like "bland" relations between actors in the HM Sjachriel Darham era. In this context it can be said, that Uncle Birin by performing the dedication of figures who understand Banjarbakula has encouraged the development of less favorable relations within the key Provincial Government internal actors in the sustainability of Banjarbakula policy.

Furthermore, in the next level of policy formulation, actor relations have not found a bigger arena. This was due to the planning contsruction of Banjarbakula KAD policy tended to wait for direction from the central government. The key actor in provincial government would be actively performing the activity if there were instructions from the central government relating to the coordination meetings between primary stakeholders of the district/city government. Seemingly this situation was a beginning of a relational decline in the intensity between Banjarbakula actors, and it could even be said that Banjarbakula cooperation policy began to be forgotten. Moreover, there was the absence of secondary actors from academics, journalists and NGOs who was demanding and criticizing the sustainability of Banjarbakula.

At the implementation level in this era, there was a phenomenon of premier interrelations in the case of Nadjmi Adhani as Mayor of Banjarbaru who lobbied and negotiated to ensure the return of Regional TPA to Regent of Banjar Regency, Khalilulrahman. The intensive interaction process and interface as well as the informal relationship made by Nadjmi Adhani to Khalilulrahman has shown result when the hand over of TPA to Banjarbaru Government happened easily. This finding wants to prove that the presence of strong actor's value preferences owned by Nadjmi Adhani has pushed the major agreements in the implementation of Banjarbakula Regional TPA. In turn that fact facilitated the Provincial Government's key actors to implement the process of inter-regional cooperation because there was a support from the cooperative relations between actors.

\section{Public Perception on Banjarbakula KAD}

This reseaerch used a quantitative approach with 32 respondents as well as informants who understood Banjarbakula's journey. The finding of this research shows that there are various perceptions related to success, expectations, capabilities, support, causes of KAD constraints to the governor era who was considered relatively successful. Below is the survey results:

As seen in Graphic 2, response to the success of Banjarbakula Program given by the respondents are around $78 \%$ stated that it was still on process and 13\% stated that it was not success/failed. The response "still on process" came from key actor bureaucrats, primary actors and academics who regretted that this program took a quite long time without any significant development. 
Graphic 2: Response to the Success of Banjarbakula Program

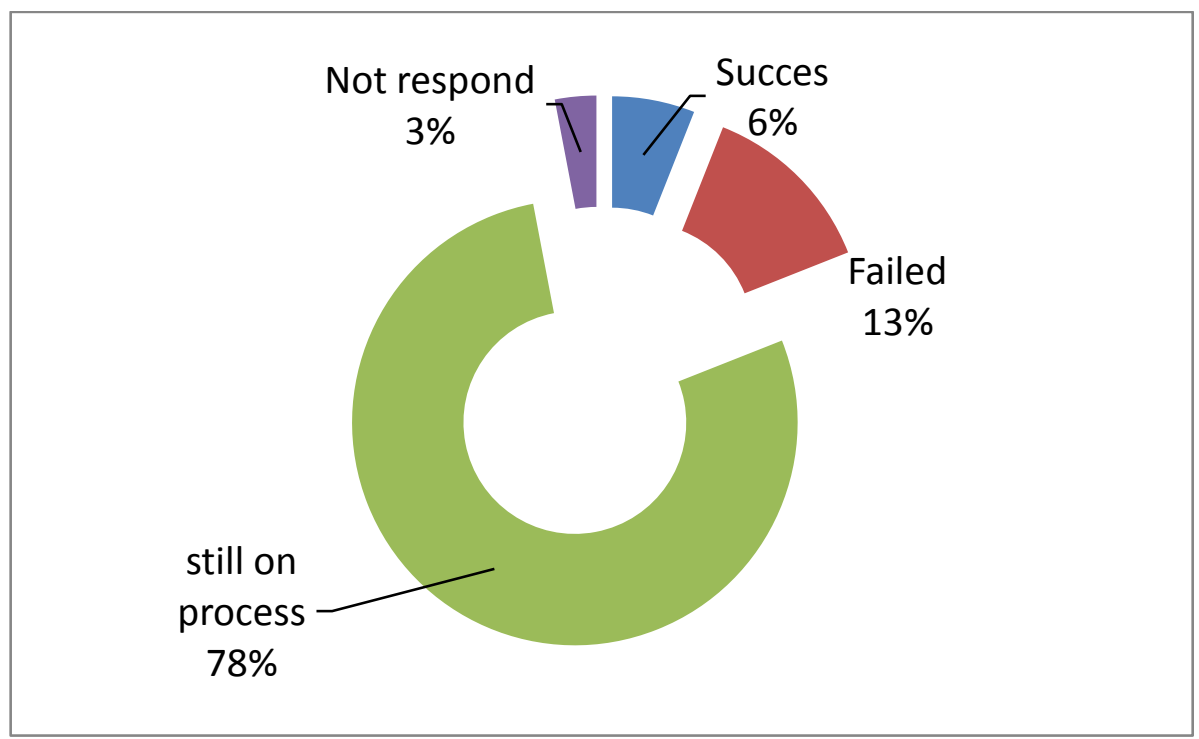

Source: Primer Data by Researcher, September 2017

In Graphic 3, generally it shows the success in the coordination aspects between interests which is around $25 \%$, the presence of infrastucture evidence is $12 \%$ and planning aspect is only $6 \%$. This fact is due to several agendas on policy activation were very dependent on the ability to coordinate activities from formulation and planning aspects. However it could still be analyzed that the ability to coordinate was dependent on how tight the actor relation in form of informal relation and intensive interaction as well as the presence of political will.

\section{Graphic 3: Aspect of the Success of Banjarbakula Program}

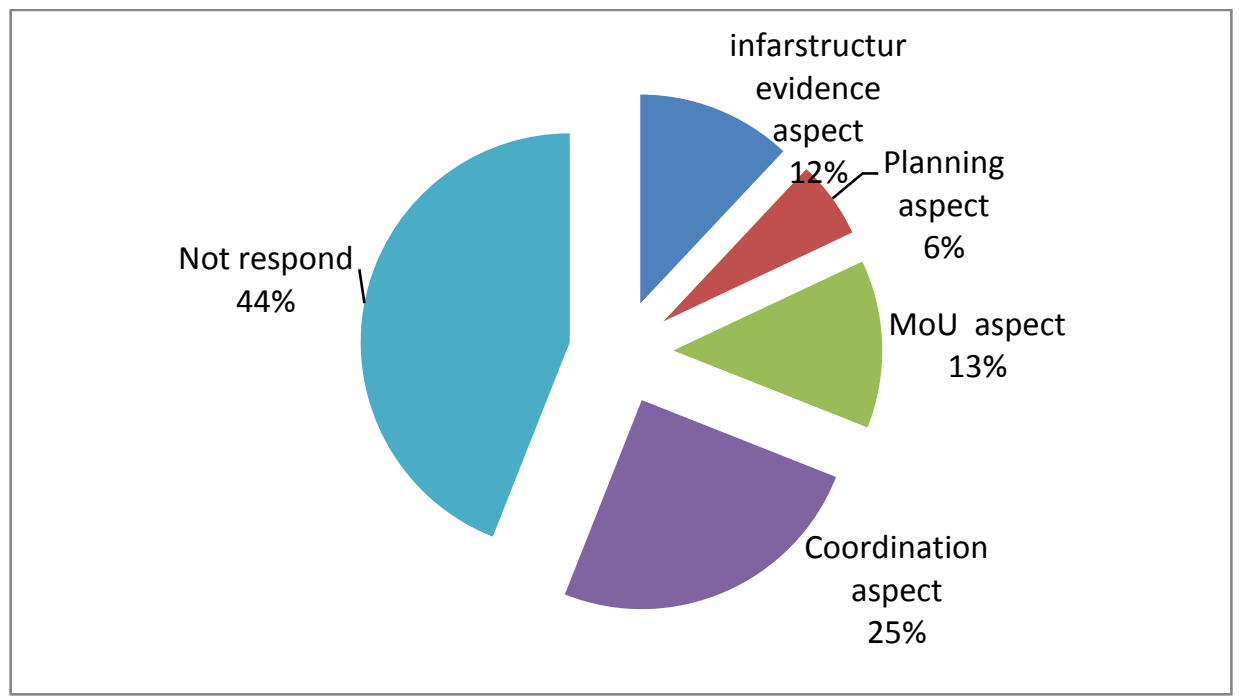

Source: Primer Data by Researcher, September 2017

Graphic 4 shows that there is around $21.87 \%$ of respondents appreciated the capability of Banjarbakula Team in Regency/City in an adequate level. The rest of the respondents (71.87\%) stated "no" and doubtful. At least the perception captured here has strengthen the informants'/actors' point of view in providing the further information on 
Banjarbakula KAD's policy, on the fluctuation case of position mutation which are inaccurate by the Head of Region based on the history of experience and competence and the ability to network.

Graphic 4: Capability of Banjarbakula Team at Regency/City Level

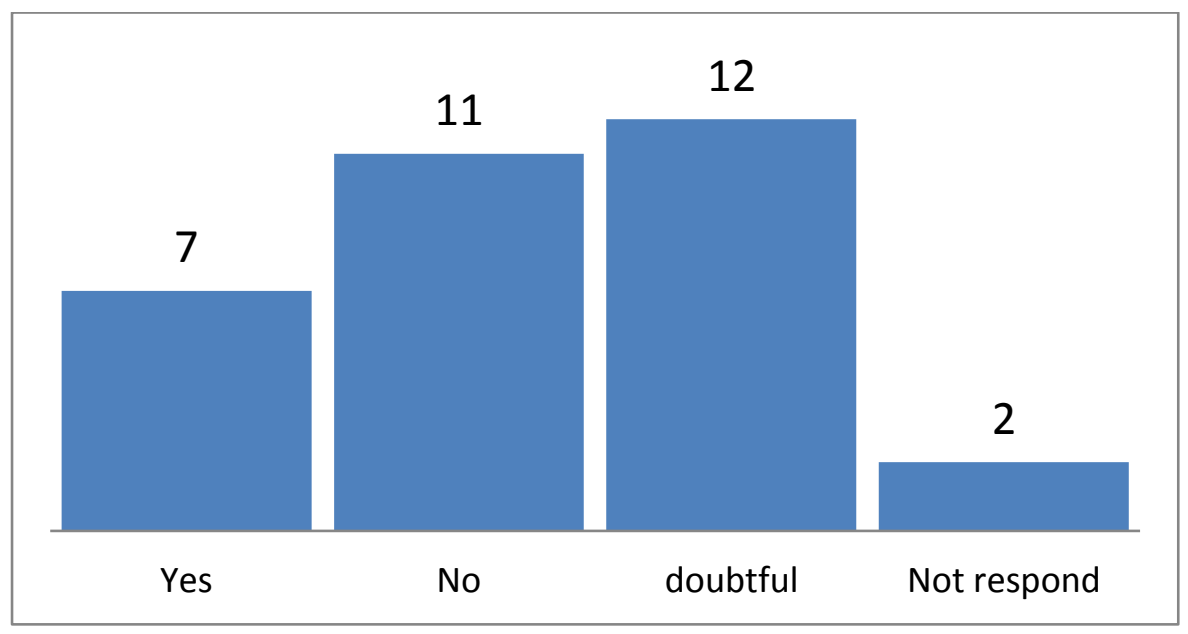

Source: Primer Data by Researcher, September 2017

In Graphic 5, there are $65.62 \%$ respondents stated that the performance of Banjarbakula Team since they first activated until now was still below expectation. The $65.62 \%$ below public expectation was based on capability, competence, and experience in the policy of inter-regional cooperation. The informants were well-awared that the agendas on inter-regional cooperations were not based only on aspects of structural relation, availability of budget, presence of coordination, and competence. The presence of high commitment from the parties in cooperation which based on the motives and agenda of interest built in the capability of intensive informal relation were also the basic aspects of inter-regional cooperations. For the informants, the policy of Banjarbakula's inter-regional cooperation which runs during four governors' administration is easy to be studied based on the supporting factors of the success of Banjarbakula's inter-regional cooperation policy with all the comparisons.

\section{Graphic 5: Expectations of Banjarbakula Team}

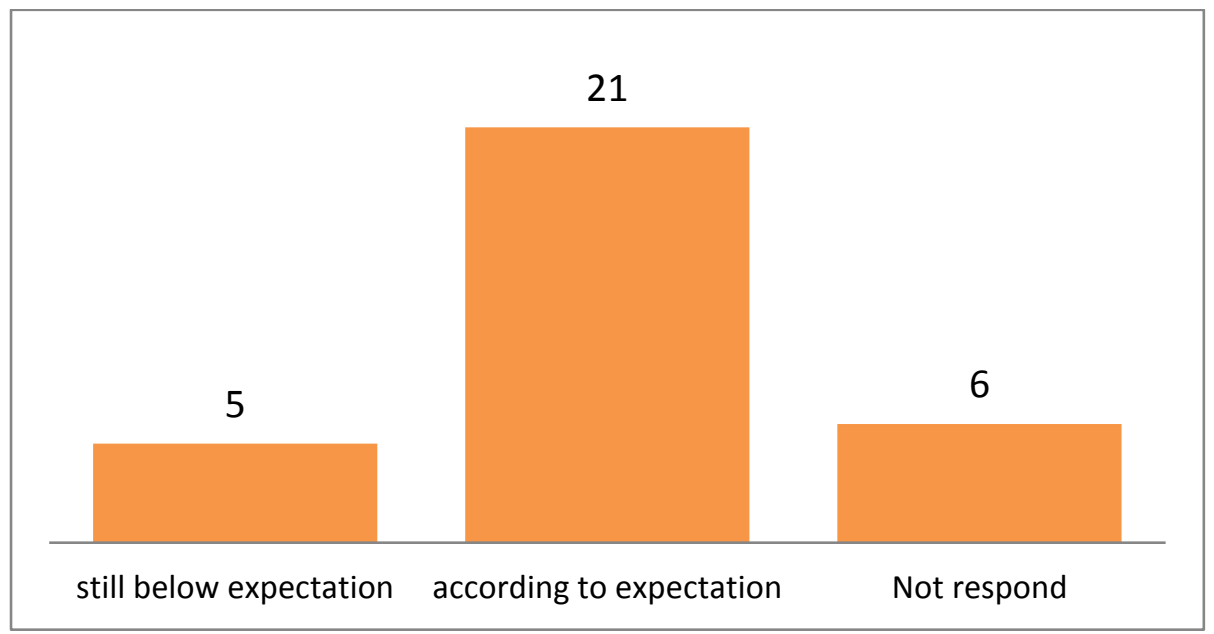


Source: Primer Data by Researcher, September 2017

As seen in Graphic 6, there are 46.87\% (15 respondents) stated that the slow progress of Banjarbakula KAD was due to the weak commitment of each head of regency/city. Meanwhile $12.5 \%$ stated that the slow success was due to the commitment of Banjarbakula team and the capability to integrate the draft of Banjarbukal KAD into the regional mediumterm development plans (RPJMD) in the provincial level as well as regency/city level. The commitment was only based on the structural relation and it was only due to the bound of relationship between actors and personnel supporting the the policy.

\section{Graphic 6: Causes of Banjarbakula Policy Inaction}

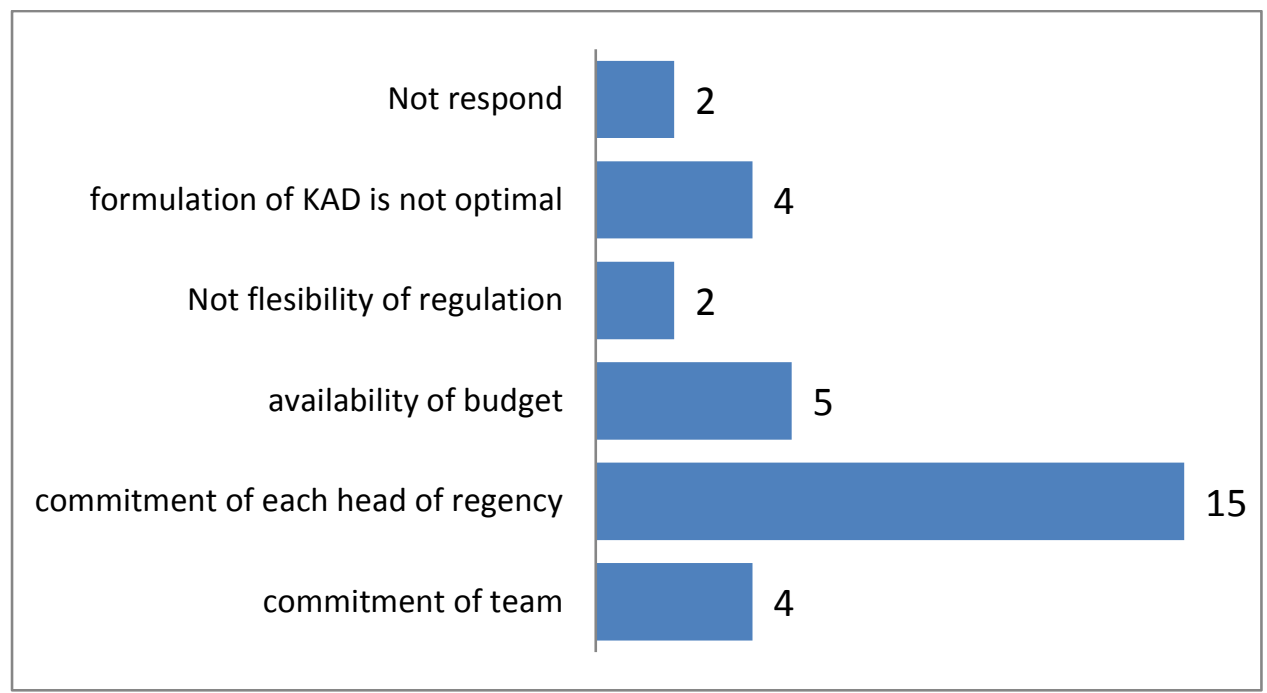

Source: Primer Data by Researcher, September 2017

Graphic 7 describes that there is a perception of respondents stated that the policy of Banjarbakula KAD was related to whether it was important or not to the regency/city involved. The availability of clean water and the handling of waste were still considered managable within themselves and they could provide the facilities themselves without any effort to cooperate.

This fact illustrates that the establishment of sectors to be cooperated sinde 1999 until now did not provide a unity in implementation for the actors in seeing the interest of Banjarbakula KAD's policy. It was recognized that during 2000 to 2015, the condition of reginal development in Banjarmasin City, the corridor of A.Yani Street, KM 6 of BanjarmasinBanjar-Banjarbaru was relatively massive. The inevitability of this development goes independently without relying on KAD Banjarbakula's plan. 


\section{Graphic 7: Compatibility of Banjarbakula Cooperation Sectors}

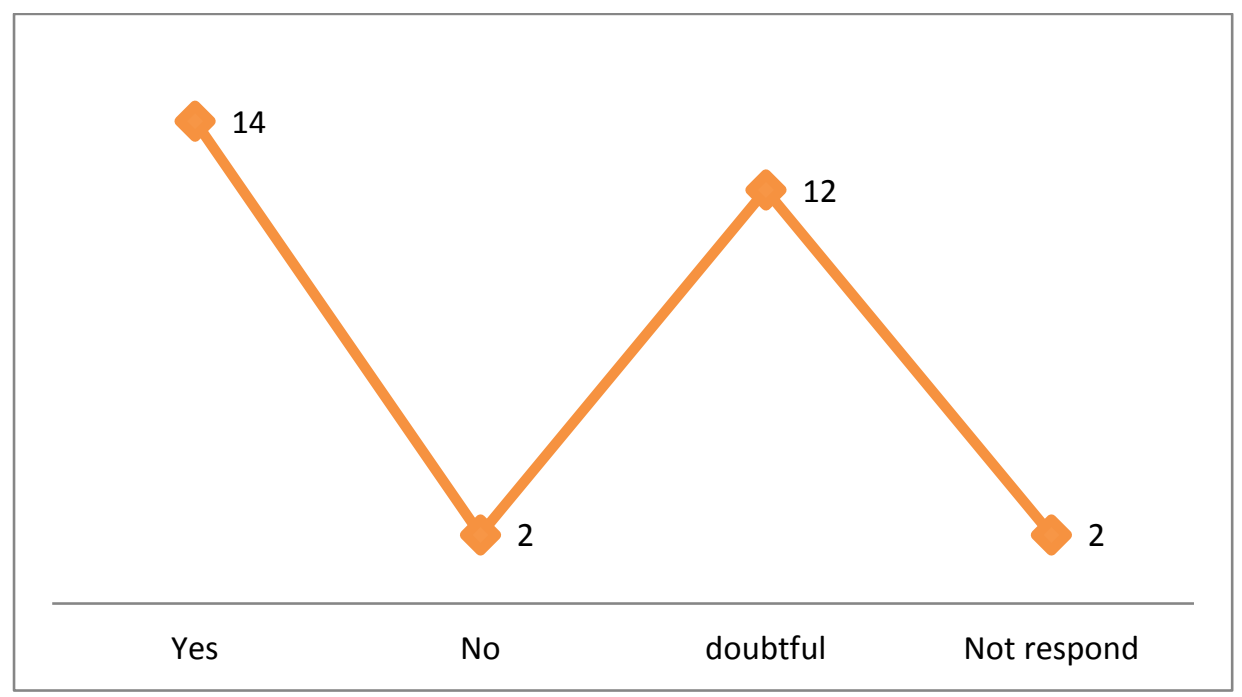

Source: Primer Data by Researcher, September 2017

In Graphic 8, from 32 respondents who provided response that the policy of Banjarbakula KAD was integrated to the regional medium-term development plans (RPJMD) in regency/city level, there was only $25 \%$ who stated "yes", $19 \%$ stated "no integrated", $44 \%$ did not respond, while $12 \%$. The fact explains that the respondents were those who understood the history of Banjarbakula and followed the policy which related to the expectation of Banjarbakula Team.

\section{Graphic 8: Integration of Banjarbakula Policy in Regional Medium-Term Development Plans (RPJMD)}

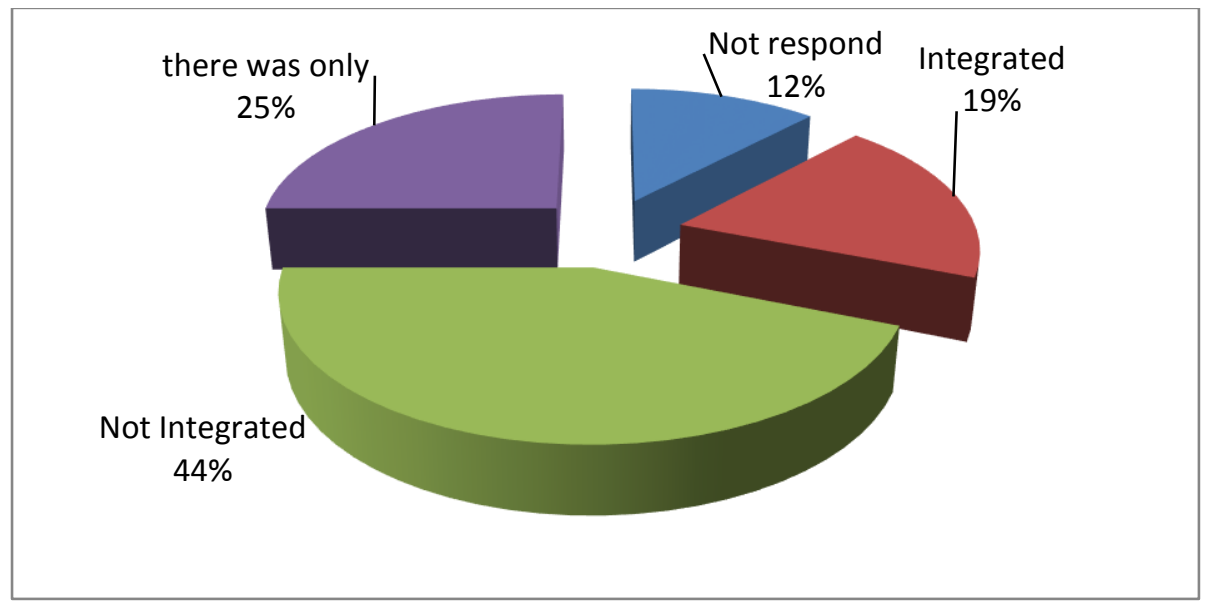

Source: Primer Data by Researcher, September 2017

As stated in Graphic 9, there are 37.55 respondents stated that they still had hope on the sustainabilty of Banjarbakula policy and $18.75 \%$ stated that it was important to have commitment in budget and program sharring. While there are $15.62 \%$ stated that there should 
be a strengthen and formation of joint secretariat/coordination tem and $12.5 \%$ stated thet there was a need to re-planning the new program. There is a high expectation from respondents on the sustainability of the program as described previously which followed by the availability of technical tools, program and other policy instruments. The instruments, among others, are the formation of Banjarbakula Joint Secretariat and the budget sharring of program fund initiated by the provincial government and regency/city government, as well as considering the aspects of informal relationship (inter-actor relation) to support the policy.

\section{Graphic 9: Actors' Expectations on Banjarbakula}

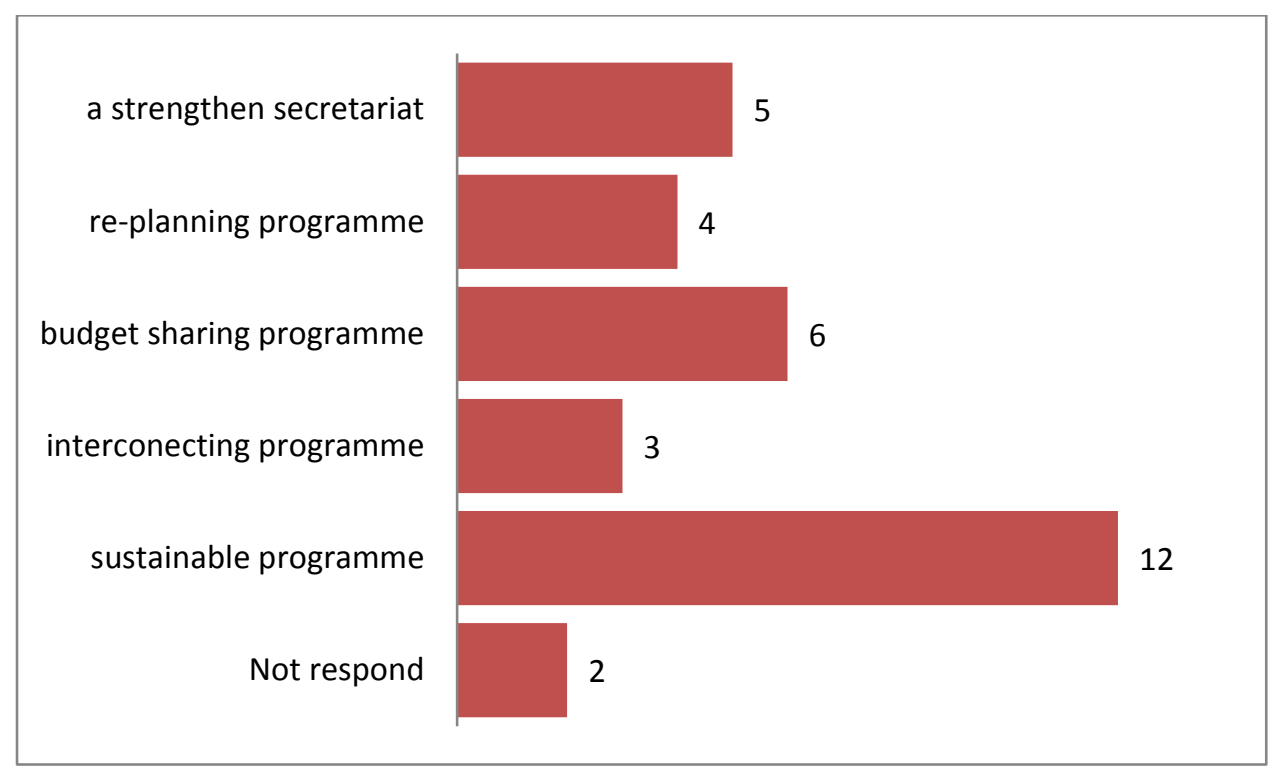

Source: Primer Data by Researcher, September 2017

In relation to support from DPRD's actor, there are $50 \%$ of respondents stated that it was relatively good appreciation (see Graphic 10). It was described in the coordination meetings and support from the Board in their statements in the print and electronic media. However there is still a very low perception on the support given by DPD RI and DPR RI. Informants gave statement related to the slow progress on turning Banjarbakula from -Provincial Strategic Region to KSN National Strategic Region, there was no statement and respect from those people's representatives when it came to the development of Banjarbakula.

Graphic 10: Support from Members of DPRD South Kalimantan Province

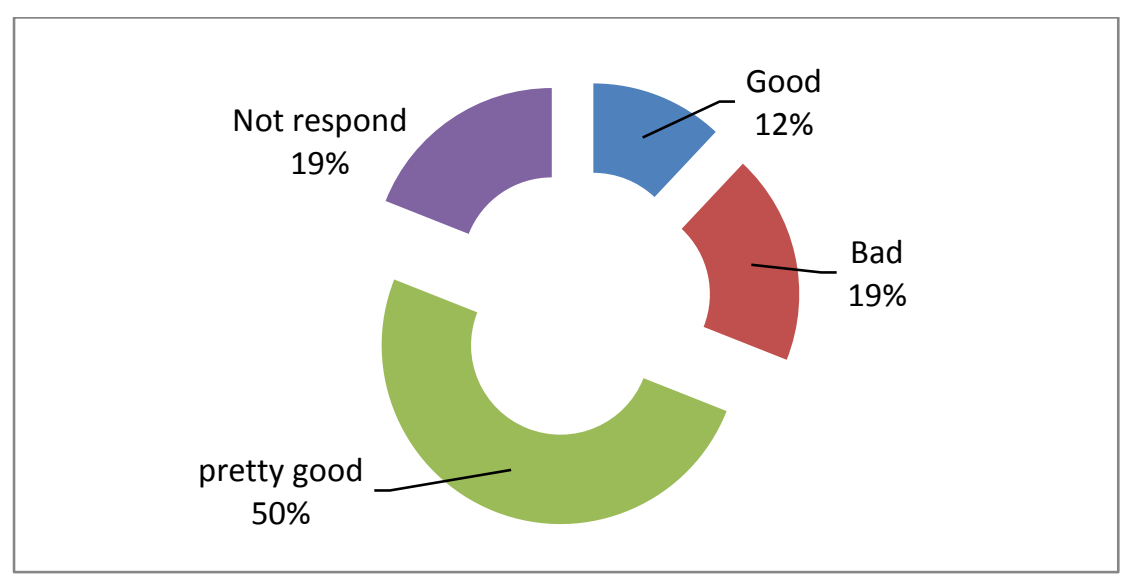

Source: Primer Data by Researcher, September 2017 
Banjarbakula KAD in each era of South Kalimantan's governor, there are differences in patterns of relations which have implications for variations in the success of inter-regional cooperation programs. Strengthening the involvement of secondary actors provides a policy dynamics and choice of relationship models. Criticism from academics, journalists and NGOs has "awakened" the key actors and primary actors in activating KAD Banjarbakula policy. Likewise, the presence of informal relations between alumni networks among actors has implications on the opening of intensive interaction and interfaces as well as cooperative relations, thus encourages the strengthening of commitment to achieving success and effectiveness of inter-regional cooperation.

Third, style or character of policy in the inter-regional cooperation is crucial in determining the level of policy formulation. The policy style in the era of H. Gusti Hasan Aman is a proactive style. That style is formed if there are high policy responsibility and community support. That style is characterized by government actors who are reformers of the policy formulation model invite other policy actors to actively participate in the participatory policy formulation process. Whereas the policy style in the era of Governor H.M. Sjachriel Darham is a survival style. Survival style assumes that in the process of policy formulation, there are low support in the responsibility and support. This is due to government actors make limitation on politicians, society and businessmen, even journalists during the process of policy formulation. The aim is to guard the success and effectiveness as well as sustainability of institutional authorities.

Then in the era of Governor Rudy Arifin, the policy style is a prescriptive style. This style is formed when the responsibility is low, while the level of policy support is high. This style places the position of government actors as political agents who have the most understanding and responsibility on the policy formulation. In this case there is a domination of government actors in every policy formulation process. This prescriptive style applies also in the era of Governor H. Sahbirin Noor. Another finding is that the turmoil of official transfers related to the expertise and experience in KAD Banjarbakula policy is one of the important factors causing the failure and ineffectiveness of inter-regional cooperation policies.

\section{References}

Aberbach, Joel D et, al.1981. Bureaucrats dan Politician in Wertern Democracies. Harvard University Press, USA.

Agranoff.R. 1996. Managing Intergovermental Processes. Dalam Handbook of Publik Administration. Perry, JL. Ed. San Fransisco: Jossey-Bass. Hal 201-231. 2003. Collaborative publik management: New strategies for local government. Washington, D.C. Georgetown University Press.

Anderson, James E. 1969. Publik Policy Making. New York;Holt, Rinehart and Winston, 2 nd ed.

Ansell, Chris and Alison Gash (2008).Collaborative Governance in Theory and Practice."Jurnal of Public Administration Research and Theory, 18(4),547571).

Brickley James A, Smith Clifford W Jr. Zimmerman Jerold L, Willett Janice, . 2003. Designing Organizations to Create Value from Structure to Strategy, New York : Mc Graw-Hill. 
Bryson, John, M. (2004). What To Do Stakeholders Matter-Stakeholders Identification and Analysis Technique. University of Minnesota. USA

Campbell, J.P. ets.1970. Managerial Behavior, Performance, and Effectiveness, New York: McGraw-Hill.

Charlotte,Intergovermental Coordination, http://www.charlottefl.com/outreach/pzdocs/EAR/SectionR.pdf,hal 1.

Creswell, Jhon W. 2012. Research Design.Pendekatan Kualitatif, Kuantitatif dan Mixed. Yogyakarta: Pustaka Pelajar.

Denhardt, Janet Vinzant and Denhardt, Robert B. 2004. The New Public Service: Serving, Not Streering. New York: M.E. Sharpe.

de Zeeuw, Gerard (2001) Interaction of Actors Theory. Kybernete 30 (7/8): 971-983.

Eyestone, Robert. 1971. The Treads of Publik Policy: A Study in Policy Leadership. Indianapolis: Bobb-Merrill.

Harmon, M. M. (1969) Administrative Policy Formulation and Publik Interest. New York: Harper \& Row

Jennings, Edward. 2005. Bluegrass Area Development Distrisct (BGADD). What Factors Lead to Succes?

Keban, Yeremian T. 2009. Kerjasama Antar Pemerintah Daerah Dalam Era Otonomi: Isu dan Strategis, Bentuk dan Prinsip. Dapat dibuka di situs: http://www.bappenas.go.id /node/48/2225/kerjasama-antarpemerintah-daerahdalam era- otonomi-oleh-yeremias-t-keban-/unduh 25 Januari 2014.

Long, N. \& Long, A. (eds.) (1992) Battlefield of Knowledge: The Interlocking of Theory and Practice in Social Research and Development. London: Routledge

Majchrzak, Ann. 1984. Methods for Policy Research, London: Sage

Osborne, Stephen P (ed).2010. The New Public Governance. London and New York. Routledge.

Rendell, E.G, and Yablonsky D. 2006. Intergovernment Cooperation, Handbook. Harisburg, Pensylvania: Department of Community and Economic Development.

Rosen, ED.1993. Improving Public Sector Productivity: Consept and Practice.

London: Sage Publication, International Educational and Professional Publisher.

Ripley, Randall B. 1985. Policy Analysis in Political Science. Nelson Hall Publisher, Chicago. 
Schmeer (1999). Guidelines for Conducting a Stakeholders Analysis. Bethesda, MD : Partnership for Health Reform, Abt Associates Inc.

Stoker, Gerry .1998. Governance as Theory: Five Proposition, UNESCO.

Thomson, AM, and JL Perry. 2006. Collaboration Process: Inside the Black Box. Publik Administration Review; 66. Academic Research Library, pp.20 -32

Thurmaier,Kurt and Curtis Wood 2002. interlocal Agreements as Overlaping Social Networks: Picket- Fence Regionalisme in Metropolitan Kansas City. Publik Administration Review, September-October 2002, page 5.

Word Bank (1996). Stakeholders Analysis. Economic \& Social Tools for Poverty \& Social Impact Analysis. USAID Publikation.

Young, Oran, R. 1992. “ The Effectivennes of International Institutions: Hard Cases and Critical Variabels", dalam James N. Rosenau dan Ernst-Otto Czempiel, ed, Governance without government: order and change om world politics, Cambridge University Press. 1992, 